\title{
LAMSCAN: Detecting rapid environmental changes through studies of annually laminated lake sediments in northern Scandinavia: linkages to the North Atlantic Ocean
}

IAN SNOWBall

Lund University, Sweden; Ian.Snowball@geol.lu.se

The LAMSCAN network was founded in 1999 in order to detect rapid environmental change through studies of annually laminated lake sediments in northern Scandinavia, and was coordinated by lan Snowball of Lund University, Sweden. LAMSCAN is one of four paleo-perspective projects that comprise a multidisciplinary Nordic Arctic Research Programme (NARP) called "Rapid Changes in the Arctic." The aim of all four NARP projects is to study natural archives of climate and environmental change. Supported by a budget of 588,000 Danish Crowns ( $80^{\prime} 000$ \$) over a period of four years, LAMSCAN funds workshops, pilot-fieldwork studies, and PhD student exchanges.

By integrating terrestrial geologists, ecologists and palaeoceanographers, LAMSCAN focuses on the identification of causal linkages between the condition of the high latitude North Atlantic Ocean and the response of ecosystems, as recorded by high resolution sediment records on the land and in the sea. Special attention is paid to the development of varved lake sediment studies in Fennoscandia, such as the potential to provide continuous records of solid winter precipitation over the last c. 10,000 years, decadal scale changes in pollen/macrofossil composition and similar highresolution records of geomagnetic field direction and intensity. As the project developed it became clear that the identification of widely dispersed Icelandic tephra shards in varved lake sediments in Sweden was a crucial building block: not only were the varve chronologies of local applicability, but they could also be used to synchronize geological archives in the North Atlantic region and assign calendar years ages to the

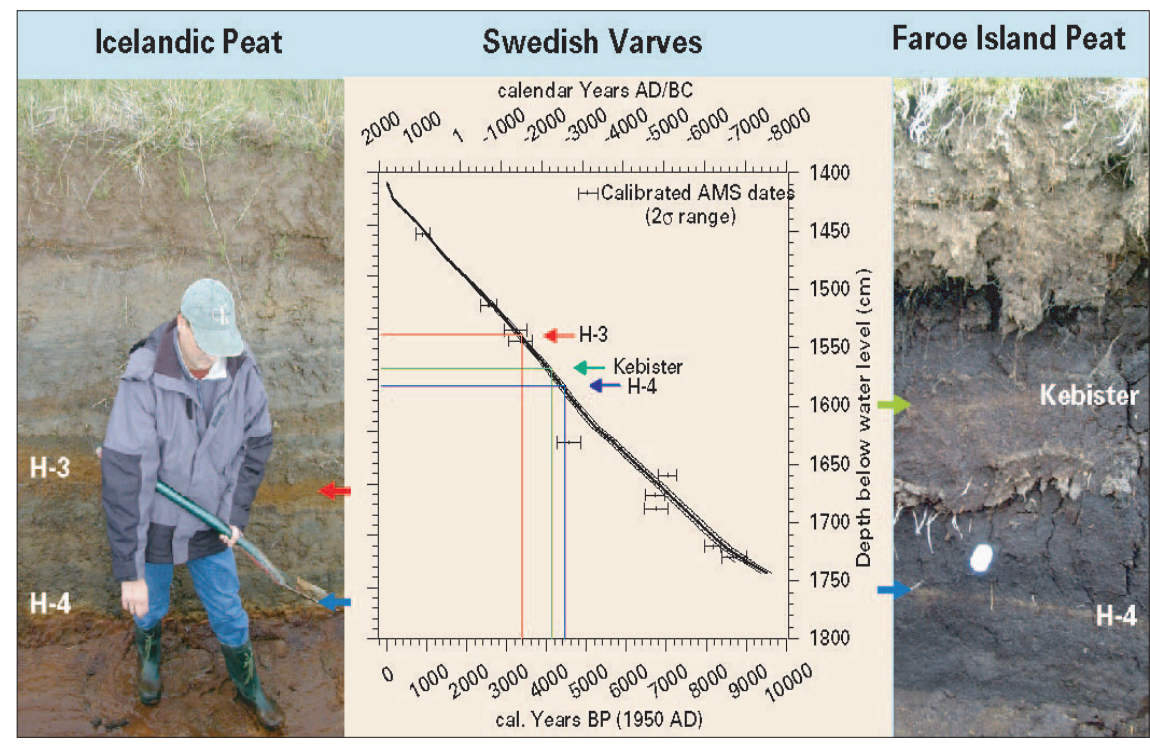

Fig. 1: Tracing, identifying and dating of Holocene tephra layers originating from the Hekla volcano in Iceland. Evidence of the Hekla volcano's explosive eruptions during the Holocene can be traced from Iceland to Fennoscandia (via the British Isles and northern Germany). Through geochemical identification and varve counting it was possible to suggest refined ages of three widely distributed Hekla tephra layers ( $\mathrm{H}-3$, Kebister and $\mathrm{H}-4)$, which can be used to synchronize terrestrial, marine and (hopefully) ice-core records of climate and environmental change (Zillén et al. 2002).

pre-historical tephra isochrons that form the central concept of tephrochronology (Fig. 1).

A recurrent theme has been the accuracy and precision of dating techniques, even for records spaning the last 2000 years, which has become a period of increased international attention. At the various workshops individual researchers often promoted the "high temporal resolution" of their specific proxy records, such as reconstructed sea surface temperatures in the northern North Atlantic, accumulated winter precipitation in Fennoscandia, or the rapid impact of climate change and human disturbance on Faroe Island ecosystems. However, the geo-chronometers currently at our disposal do not allow us to synchronize potential decadal-scale reconstructions of pre-historical ocean-atmosphere interactions in the North Atlantic (such as the North Atlantic Oscillation) to their terrestrial counterparts. When this high-resolution synchronization is achieved our understanding of climate dynamics and environmental change in the high latitudes will take a large leap forward.

Information about the NARP networks can be found at: http://www.thule.oulu.fi/narp/

\section{ReFERENCES}

Snowball, I.F., Zillén, L and Gaillard, M-J., 2002: Rapid early Holocene environmental changes in northern Sweden based on studies of two varved lake sediment sequences. The Holocene, 12, 7-16.

Zillén, L.M., Wastegård, S. and Snowball, I.F. 2002: Calendar year ages of three mid-Holocene tephra layers identified in varved lake sediments in west central Sweden. Quaternary Science Reviews, 21, 1583-1591 